Article

\title{
The Relationship between the Use of Building Performance Simulation Tools by Recent Graduate Architects and the Deficiencies in Architectural Education
}

\author{
Maria-Mar Fernandez-Antolin ${ }^{1, *} * \mathbb{C}$, José-Manuel del-Río ${ }^{1}\left[\mathbb{C}\right.$, Fernando del Ama Gonzalo ${ }^{2}$ and \\ Roberto-Alonso Gonzalez-Lezcano ${ }^{1}$ (D) \\ 1 Escuela Politécnica Superior, Universidad San Pablo-CEU, CEU Universities, Montepríncipe Campus, 28668 \\ Boadilla del Monte, Madrid, Spain; jmdrc.eps@ceu.es (J.-M.d.-R.); rgonzalezcano@ceu.es (R.-A.G.-L.) \\ 2 Department Sustainable Product Design and Architecture (SPDA), Keene State College, Nuevo Hampshire, \\ Estados Unidos, 229 Main St, Keene, NH 03435, USA; fernando.delama@keene.edu \\ * Correspondence: mariamar.fernandezantolin@ceu.es
}

Received: 20 December 2019; Accepted: 27 February 2020; Published: 3 March 2020

\begin{abstract}
This paper examines the actual knowledge regarding Building Performance Simulation Tools (BPSTs) of recent graduate architects in Spain. BPSTs quantify aspects of building performance that are relevant to design, construction, and operation. Recent graduate architects are those who have been awarded a first degree from a university or college and face their first professional experience. This article aims to identify the deficiencies within the current curricula of Spanish universities relating to BPSTs. The authors have surveyed 171 recent graduate architects, and the analysis of the data reveals the deficiencies in university education. Regarding the collected results, the Spanish university syllabi must undergo necessary modifications to encourage the use of simulation as a part of university training courses. The incorporation of energy simulation in such training courses can provide recent graduate architects with tools that would assist them during the design stage. The use of these tools is key in the development of innovative pedagogy-based teaching materials for the courses. In this sense, the present work aims to delve into the usage deficiencies associated with BPSTs and propose ways in which to bridge the gap between higher education and first professional experiences.
\end{abstract}

Keywords: Building Performance Simulation Tools (BPSTs); training in energy simulation tools; architectural design; education in university

\section{Introduction}

Climate change and the shortage of energy resources are two significant challenges to be faced in the near future [1]. In the US, buildings consume $48 \%$ of the total energy [2]; in Europe, $40 \%$ [3]; and in the Arab Emirates, 70\% [4]. Therefore, countries have issued directives that encourage Net-Zero-Energy Buildings (NZEB). With the help of energy simulation, only the buildings that comply with such regulations are eventually built [5].

Simulation is a psychological and social discipline, because it involves interaction between man and computer [6]. The human dimension is one of the most critical performance indicators, since deep understanding of it allows for progress in the development of simulations [7]. This discipline arose in 1960, when the US government carried out projects to evaluate the environment in fallout shelters [8]. During the 1980s, they began to develop the tools of Simulating Building Behavior (BPSTs) to help architects in their analyses [9], but it was not until a decade later that they began to actually use simulations [10]. In 2010, the number of tools listed in the Directory of Energy Software Tools for 
Buildings (BESTD) reached more than 350 (DOE, 2010), which means that between the periods 1997 and 2010, the number of tools quadrupled. However, less than 40 are intended for architects [11].

The growth of the use of energy modeling in architecture has become evident at the international level, according to the American Institute of Architects [12]. This evidence shows the commitment of the profession in the USA to integrating energy modeling processes within the design practice, but, according to other studies, there is a disconnection between the design stage and architectural simulation [13]. During the design process, the goal of architects is to reduce the thermal loads of the building. However, the owner and the designer have, by this stage, already made the most important decisions related to the shape and orientation of the building, and once they have become acquainted with the design, it is not possible to change these decisions. During the simulation process, thermal models are developed, from the detail to the whole, in a manner opposite to the architectural design process [14].

There is a widespread belief that existing energy simulation tools do not fit the needs of architects for achieving energy efficient buildings in the early stages of design $[15,16]$. Thus, architects do not consider the modeling of energy as their responsibility [17]. There is a tendency to adapt BPSTs to new needs in architecture, such as geometric representation [18], as well as the means of communicating and representing a design [19]. There is usually a non-intuitive user interface [20], and simplification becomes essential in its development [21]. BPSTs require the entry of a large amount of data [22], and this happens to be one of the main challenges for architects [23].

There is a simplified method to handle BPSTs, which is used to minimize the execution time and does not require a large amount of data [24]. Architects use this method to deal with the initial design requirements [25]. According to other studies [26], complicated simulation tools do not provide better support for the decision-making process, so architects find more advantages in simple energy simulation tools than in complicated ones. In terms of the results offered by BPSTs, their output is excessive and complex and it lacks visual quality, as architects seek to represent analysis results within the 3D geometric model [27]. Additionally, the obtention of significant information from BPSTs requires expert knowledge, since the information must be handled to apply it in the decision-making process of building design [28].

The attention paid to climate change will lead to increased interest in the coming years, so universities must engage in the development of more specialized curricula [29-31]. There is an urgent need to create multidisciplinary teams in building decision-making that understand the impact of climate on cities [32]. The first postgraduate study that focused on this in Europe was in 2014 at Cracow University of Technology in collaboration with the Polish Green Building Council [33]. It indicated that there is an urgent need to incorporate sustainability courses into architecture programs. Other researchers have developed a methodology to optimize the architectural design, focusing on energy consumption [34].

In Europe, there is great interest in incorporating new educational approaches into the curricula that can enable experts to design energy-efficient buildings $[35,36]$. Students consider sustainability to be a critical aspect of their architectural education. However, nowadays, sustainability is taught in lecture-based courses, with little integration in design studios [37]. In Germany, there are studies of the student's ability to become a consumer or interpreter of simulations. These studies indicate the urgent need to introduce BPSTs technologies into the architectural domain through research in Europe [38]. Finally, in Spain, the amount of environmental content is below 10\%. The introduction of environmental contents in the curricula of the Spanish Schools of Architecture is somewhat difficult due to the current structure of these schools and their rigidity. However, some tools and methodologies can facilitate a gradual evolution towards a change in paradigm in the architectural conception and a teaching change in the long term [39].

Currently, architects are beginning to use the new energy modeling tools, but their participation is still poor [40,41]. On the other hand, there must also be a change in architectural education [42,43], since professionals find difficulties both in the interfaces and in the analysis parameters. The inclusion 
of energy simulation tools in university syllabi will result in better communication between architecture and other disciplines [44,45].

Energy simulation and architectural design have traditionally been considered as separate elements in the design process [46-49]. In architecture, a building consists of elements, but an energy model is composed of thermal areas [50]. Other studies deal with the different uses of energy simulation by several users, particularly architects, and conclude that the use of technology could allow for a broader range of decisions [51]. While there are few empirical examples of the use of energy simulation by architects, recent studies explain how leading companies can develop know-how about the types and range of parameters to be handled by BPSTs [52-54].

Some articles show that the design of an Applied visual interactive Building Regulation (AviBR) takes into account both educational and pedagogical factors, contributing new knowledge to the field of pedagogy by combining interactive visual aspects with online education. AviBR applications are used in education as a teaching tool [55]. This problem is clearly defined, but more research and development are needed to overcome these deficiencies in education through practical application [56,57]. University training is the only path toward solving this issue $[58,59]$.

In education, sustainability training in teaching is insufficient for architects [60], and there is a lack of knowledge transferred to outside professionals [61]. There is also a need to strengthen the education system's “Environmental Design in University Curricula and Architectural Training in Europe" (EDUCATE, 2009) [62].

Therefore, the main objective of this research is to evaluate the usage deficiencies associated with the current energy simulation tools in architectural practice by examining their utilization by recent graduate architects. The second objective is to propose solutions and measures to improve architectural curricula. The central question to be answered is: How do recent graduate architects currently evaluate the deficiencies associated with their training in BPSTs?

\section{Materials and Methods}

An online survey (Appendix A3) was sent by email to recent graduate architects. The questionnaire was forwarded by email, as well as distributed via LinkedIn, Twitter, and Facebook. The data collection was conducted both online and through face-to-face interviews (workshops). A survey was designed, in which many parameters, defined in Supplementary A1 and Supplementary A2, were analyzed. The survey population is recent graduate architects in Spain. The experience of $86 \%$ of the respondents was less than 5 years old, and $33.9 \%$ of them had not yet started their professional careers. The survey is not intended for architects with a long professional career or experience, but rather for recent graduate architects of an average of 25 years old. Of the projects in which they usually participate, $72 \%$ are residential or associated with rehabilitation. As for their architectural practices, $38.6 \%$ were related to design and construction.

The responses received from the survey were analyzed using a statistical program (SPSS) [63]. The qualitative data were processed in excel sheets. The responses were coded, making it easier to understand and extrapolate the results. On the other hand, researchers were asked to apply consistent measures [64] to ensure that the findings of their research are reliable. First, the level of confidence with which the estimate is to be considered and the maximum tolerable error margin concerning the sample size are taken into account. A representative sample is considered to obtain consistent estimates

$$
\mathrm{N}=\mathrm{Z}^{2} \times p \times \mathrm{q} / \mathrm{d}^{2}
$$

where: $\mathrm{N}=$ the number of completed responses by recent graduate architects; $\mathrm{Z}=$ the confidence level; $p=$ the probability of success; $\mathrm{q}=$ the probability of failure; $\mathrm{d}=$ the precision (maximum permissible error); $\sigma 2=p \times \mathrm{q} ; \sigma=$ the standard deviation; and $p=\mathrm{q}=0.5$, when the success is unknown.

$\mathrm{Z}=1.96$, with a confidence level of $95 \%$. If $\mathrm{n}=171$, then the error $=\mathrm{e}=0.0757 .5 \%$.

$\mathrm{Z}=1.28$, with a confidence level of $90 \%$. If $\mathrm{n}=171$, then the error $=\mathrm{e}=0.0494 .9 \%$. 
Second, Cronbach's Alpha is used to measure the reliability of a scale of measurement for the designed questions. Other studies already examined the reliability using Cronbach's Alpha [65], obtaining a result between 0.81 and 0.96 . Additionally, it has been suggested that Cronbach's Alpha values greater than 0.7 indicate a considerably high reliability, whereas values from 0.35 to 0.7 indicate a moderate reliability [66].

\section{Results}

Participants from Spain answered the survey, and 171 valid answers were received. The analyses of the research results are shown and discussed below, and the quantitative data and qualitative comments received by the respondents are provided.

\subsection{General Research Findings: Non-Users and Users}

The respondents considered the survey to be complex, since even questions for non-users were quite technical. This occurrence indicates that many of the respondents had never heard about BPSTs. It is clear that there is a lack of real and practical guidelines that make users realize the benefits of using these tools. Figure 1 shows that, in Spain, the use of these tools is not yet implemented among recent graduate architects, and $70.8 \%$ of respondents indicated that they have never used an energy simulation tool. This is because they do not consider it to be their responsibility.

a

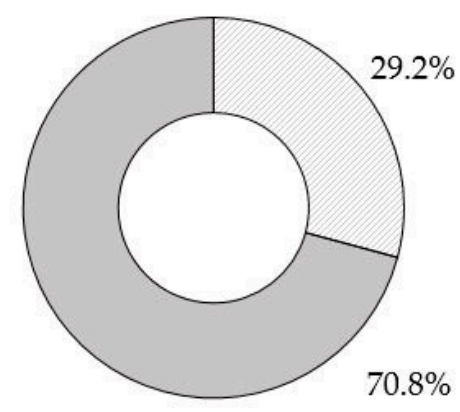

$\square$ Yes

$\square$ No

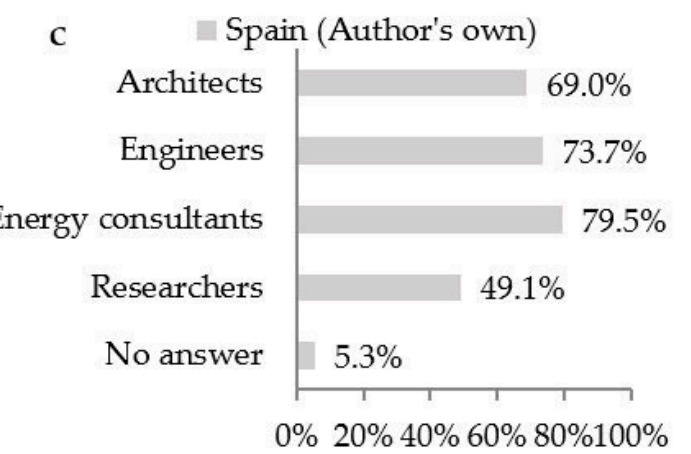

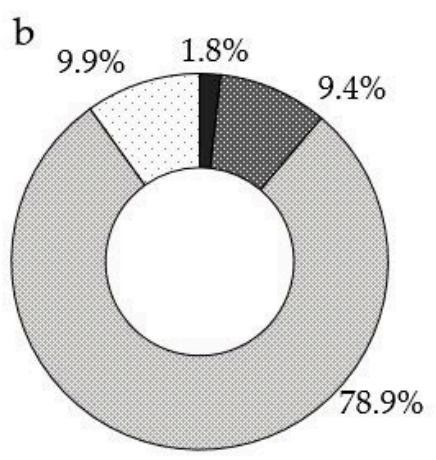

Fully agreed $\square$ Disagreed $\square$ No answer

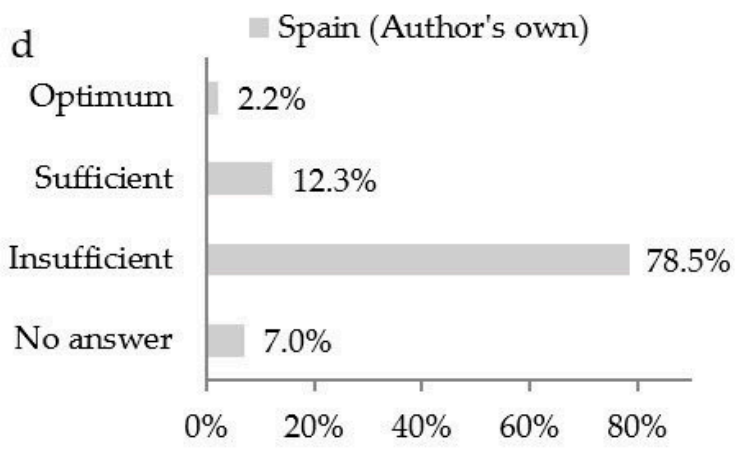

Figure 1. Analysis of the participants surveyed, according to their use of building performance simulation tools (BPSTs). (a) BPST Users and Non-users. Have you ever used BPSTs? (b) Building design can be substituted by quantitative simulation software; (c) The type of user who works with BPSTs; (d) Architects' knowledge levels concerning BPSTs.

This is indicated in comments such as: 
"It is not my competence with respect to the work I develop. I work in a company where there is a team that is specifically responsible for this issue. Other team members (engineers) take care of that".

Of the recent graduate architects, 69\% indicated that, although this is an issue that affects them, their level of knowledge is clearly insufficient. BPSTs are not used in universities, and this results in a clear lack of training. They consider that every technological advance in energy modeling is largely outside their domain. Therefore, according to their viewpoint, the responsibility belongs to other experts. They suggest that greater emphasis should be placed on energy performance within architectural training and professional development for architects. Some of the comments collected in the survey regarding collaboration with other professional teams are shown here below:

"Given my lack of experience in this field, I believe that for the decision-making processes, an expert should help to provide reliability. Multidisciplinarity is necessary, so that simulations can be conducted by different professionals."

\subsubsection{Definition, Objective and Design Parameters}

Regarding their previous knowledge of BPSTs, the majority of respondents believed that energy simulations started to be used in 1990. They considered that the evolution of BPSTs has quadrupled (41.5\%) from 1997 to 2017 . However, $36.3 \%$ did not have any information about the development of the tools, and 52.6\% considered that an energy tool is used to optimize buildings, but they did not consider it a tool to help them set up their architectural design. Regarding the objective of simulation, 58.5\% of respondents indicated that they are interested in reducing the energy consumption of a building.

Several considerations have been collected about the definition of energy simulation. The participants declared that it is a tool that offers data intended to improve the energy performance of a building. Thus, BPSTs are considered to help achieve an optimal and sustainable model. Everyone agreed that these tools improve the design and construction of buildings and allow for energy saving. Similarly, they thought that all types of buildings are predicted and analyzed from an energy viewpoint throughout their life cycle. One of the technical comments is shown below:

"Virtualization of the energy performance of a building optimizes the cost of its construction, operation, and reduction of its carbon footprint."

With respect to the objectives set in the simulation, it is indicated that, from a design point of view, the gains and losses of buildings are to be diminished and/or reduced. Some respondents indicated that they did not know how to describe the objectives of the simulation but that they would like to know more about them. Another answer states:

"The control of the costs generated by the activity of the construction, from the manufacture of materials until the demolition of the building, helps avoid energy waste. It takes advantage of resources in the most efficient way, maintaining a standard of comfort for the occupants of the building."

The responses to the question about what parameters are relevant when it comes to using BPSTs indicate that openings (81.9\%) are the most important ones. $73.1 \%$ of respondents said that climate data and HVAC systems have to be taken into account in Building Simulation. The importance of other parameters, such as outdoor shadow (52\%), or environment $(49.7 \%)$, does not seem to be as relevant as the others.

Architects are urged to support their designs with BPSTs and to improve architectural integration $(39.8 \%)$ and the preliminary dimensioning of energy systems $(19.3 \%)$. For construction and orientation, however, they do not consider them as something crucial $(8.8 \%)$.

\subsubsection{Use of Tools at Design Stages}

The existing architectural tools are not suitable for the decision-making process of architects. They are not easy to use during the exploration and the conceptual stage of design. Many well-defined 
input data are needed, and the interpretation of the output results requires expertise. According to the Royal Institute of British Architects (RIBA), accuracy is less important during the design stage, which allows for the development of creativity and provides quick results in a language that can be easily understood by architects. In the early stage of the design process, BPSTs must allow for an output of results that are understandable by non-experts, with the minimum number of input data. The requirements to be taken into account in this stage should be easier to use, more versatile, more robust, better documented, and with a minimum time for obtaining the output result. The detailed results must meet the needs of architects for a high-standard design [67].

Six energy modeling tools are reviewed in another research work [68], including Ecotect, IES/VE - Sketch-Up, Energy10, eQuest, HEED, and Design Builder. Of all the respondents, 171 of them use Autocad as a working tool, 70 use Sketchup, and only 20 of them use Ecotect. Very few of the respondents use more advanced simulation tools. Design Builder is used only by 16 of them.

Most of the reviewed tools did not show an adequate applicability or ease of use in the design decision-making processes of most architects. Bad communication and visualization of the output results are detected as the main limitations. In future research, we propose working on this aspect of adequacy with regard to the exported results.

Regarding modeling, the respondents did not understand the difference between thermal models and architectural design models, since $49.7 \%$ considered that the geometric definition should be as detailed as possible, and $67.3 \%$ had never heard about the simplification of a geometry to simulate buildings energetically. According to Attia, S. et al., 2010 [69], Ecotect is the tool most used by architects, while Sketchup is used by $58 \%$. In Spain, $55 \%$ of recent graduate architects have never used a BPST, and the tool used most for energy calculations is Sketchup. Most architecture students and graduates should know the LIDER-CALENER tools, because they are mentioned in the Spanish building code. However, this study indicates that only $5 \%$ of respondents had used those tools. Surveys carried out within architecture companies in the United States, the United Kingdom, Australia, and India found out that in most cases, architects recognized the importance of early-stage energy modeling, but they did not implement it greatly in their design practice for different reasons.

Figure 2 shows the skills in BPSTs and the stage of the design process in which these tools are used. More than $70 \%$ of respondents declared that their knowledge of the CAD software is advanced or far advanced. This figure drops to $10 \%$ when it comes to the knowledge of BPSTs. The respondents use CAD tools during all stages.

\subsubsection{University Training of BPSTs}

According to other research works [65,66], more than half of respondents $(64.9 \%)$ use energy simulation tools, such as IES, eQUEST, and Energy plus. However, Graph A in Figure 2 shows that only $35 \%$ of recent graduate architects use BPSTs in Spain. Energy simulation is used most at the detailed design stage $(26 \%)$, but not during the initial design stage, and much less in the conceptual stage.

Some researchers suggest that designers tend to rely initially on experiential knowledge, rather than on simulation tools [70], and BPSTs are therefore considered primarily as validation mechanisms, rather than exploration tools. During the early stages of design, little information is available, and flexibility is needed, so BPSTs are used to support design decisions, because these tools require many data and little flexibility [67]. 
A

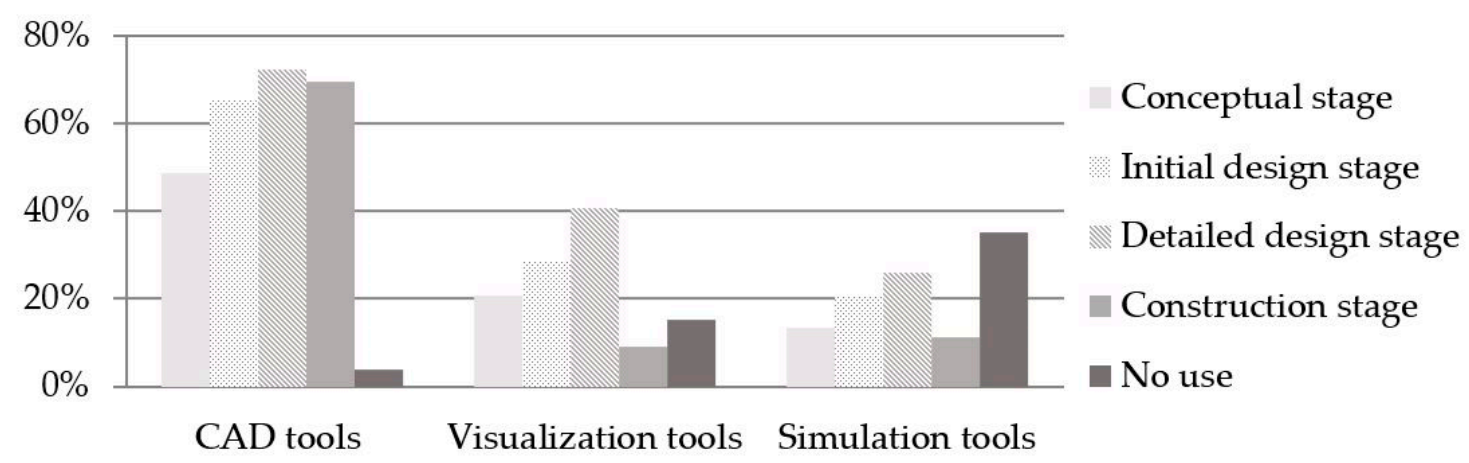

B

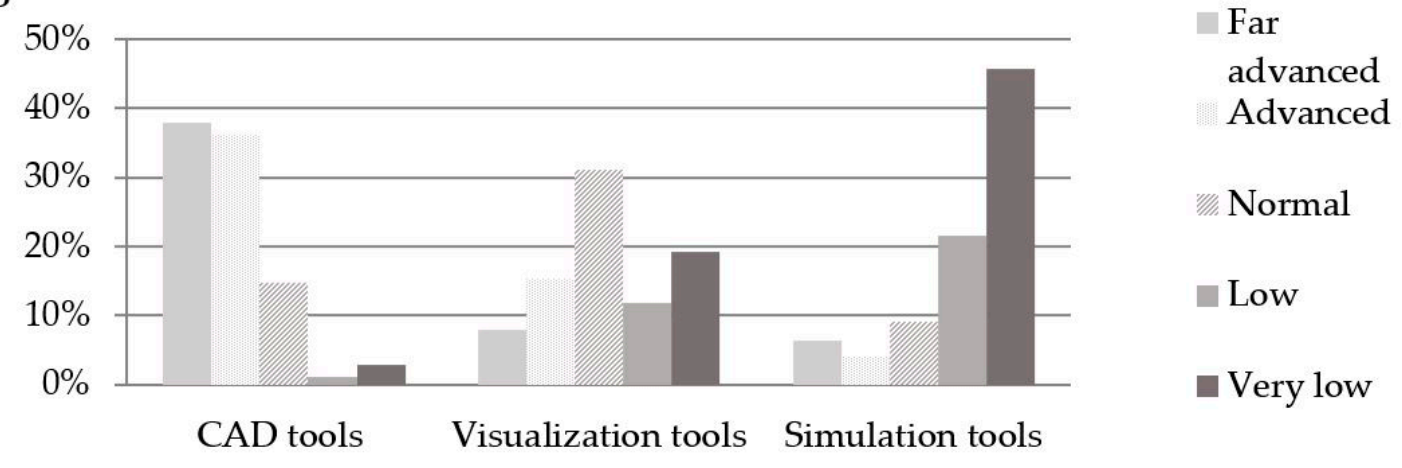

Figure 2. (A) In which stage of the design process do you use BPSTs? (B) What are your skills in the use of the following software? (Addressed to non-users and users).

\subsubsection{Reasons for Not Using BPSTs}

When it comes to the reasons for not using BPSTs, $42.1 \%$ of the respondents stated that lack of know-how is the main issue. Many of them (29.2\%) had never heard of these tools, and 26.9 of them do not perceive that BPSTs are needed. The respondents did not think that the tools are expensive, with only $0.6 \%$ respondents suggesting costs being prohibitive, and only $7 \%$ assumed that simulation tools are cheaper for students. Some of them held that the software should be free (27.5\%), and other respondents considered that a simulation program license is inferior to that of CAD $(22.25 \%)$. The main reason for not using BPSTs seems to be rooted in the fact that they are not perceived as necessary at any design stage. If senior students have not heard of these tools, it is very unlikely that they become users in their professional experience.

When accomplishing simple projects, most of the respondents would perform the simulations themselves (50.3\%), although a significant percentage of them would involve an external consultant $(33.9 \%)$. Customers do not demand the use of BPST, so the architecture market is not updated. Some respondents did the calculations intuitively and had never used the energy simulation programs. They held that BPSTs do not provide reliable results. Therefore, they considered that the experience, training, and knowledge of the expert should prevail. Other respondents stated that BPSTs do not help them to shape a building volumetrically.

Figure 3 illustrates the responses concerning the mechanisms available for the optimization of building energy performance and their influence in the architectural design. Of the respondents, $85.3 \%$ stated that an architect's ability and experience is the mechanism that helps him/her to optimize buildings, followed by design guidelines (43.3\%) and collaboration with other architects (44.4\%). Of the respondents, $57.9 \%$ considered that collaborating with other professionals in multidisciplinary teams can help incorporate decisions made by the energy consultant, without damaging the architectural design, and $89.1 \%$ acknowledged that BPTS makes architects reconsider several aspects previously 
ignored during the design process. A lack of knowledge was considered by $70.8 \%$ of respondents to make stakeholders lose trust in BPST.

i49.Building design depends on architect's ability and experience

i52.BPSTs enable architects to reconsider several aspects previously ignored during the design process

i53. Considering energy-efficiency aspects at the design stage hinders the functional design of buildings

i54.An optimum shape design of buildings is effective to avoid the use of blinds, awnings, and other shading devices

i57.BPSTs raise confidence for taking architectural decisions

i58.Lack of knowledge in BPSTs is what makes stakeholders not to trust them

i60.In order to obtain confidence, It is important to collaborate with experts in simulation software
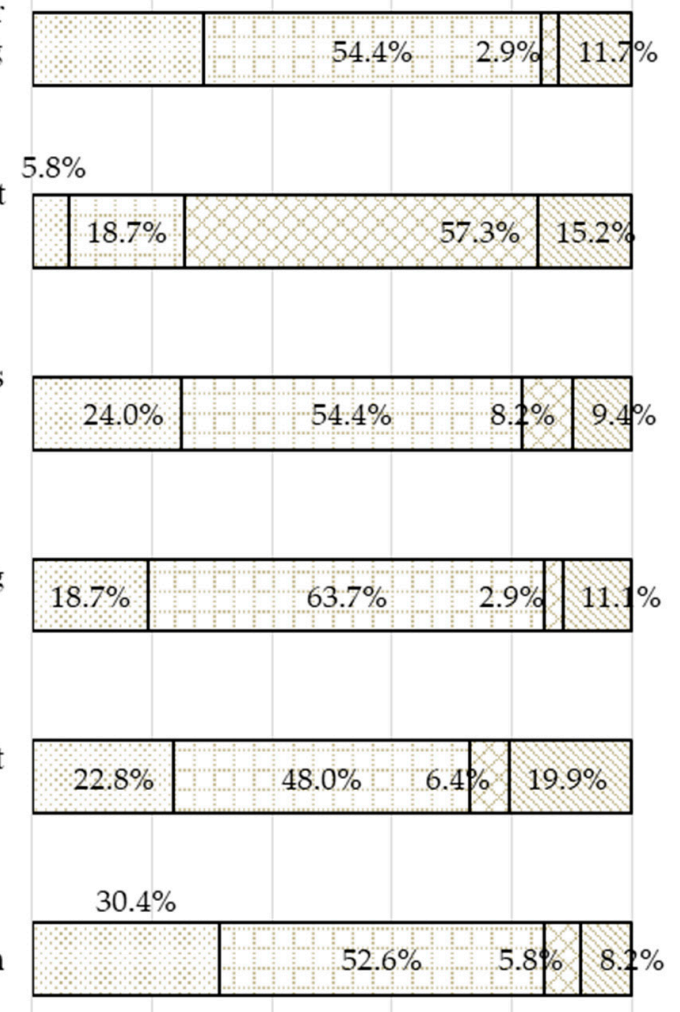

$4.7 \%$

i61.Professionals using BPSTs have an absolute control on its parameters

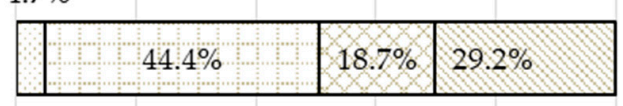

i63.It is possible to incorporate every decision made by an energy consultant in $11.7 \%$ the design without damaging it

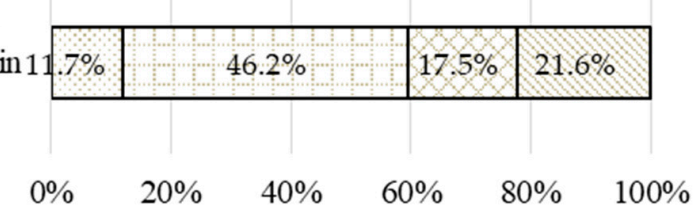

Figure 3. Relationship between BPSTs and architectural design, professional use, and the characteristics of BPSTs (respondents were users and non-users of BPSTs).

Figure 4 shows that $73.7 \%$ of respondents regarded BPSTs as useful in designing NZEB. Further, $67.3 \%$ of the respondents considered that the best stage in which to make use of an energy simulation is during the detailed design stage, and 59.1\% stated that BPST can help architects create the geometry of the building at the conceptual stage, although only $16.4 \%$ had used BPSTs at work. The learning of simulations was associated with a trial and error process by $65.5 \%$ of respondents. 


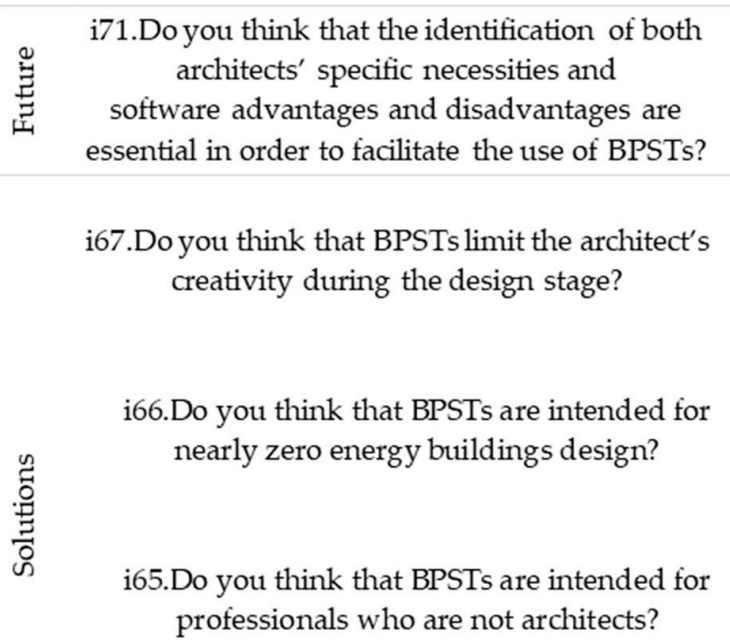

i62.Are you interested in the use of BPSTs in the future?

i59.Do you think that the data obtained through simulation software are correct?

i46.Do you think building simulation is essential before its construction?

i44.Do you think that simulation software can help you create the geometry of your architectural work?

i43.Do you think that BPSTs speed up the design stage?

i35.Do you use BPSTs tools at work?

i34.Do you think that the validation of outcomes (through comparison with real results) is

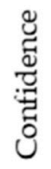

i33. Do you think that BPSTs learning should be carried out by trial and error process?
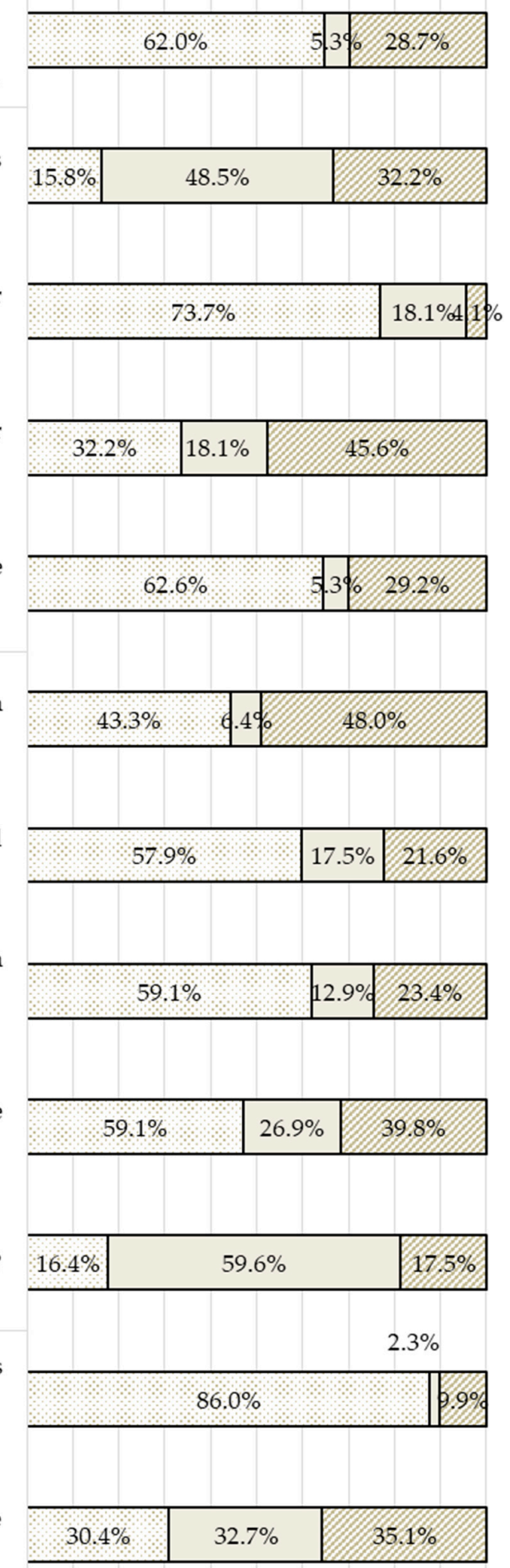

0\% 10\% 20\% 30\% 40\% 50\% 60\% 70\% 80\% 90\%100\%

Figure 4. What are the reasons for and against using BPSTs? (Addressed to non-users and users). 


\subsection{General Research Findings. Users}

First, $64 \%$ of users had not taken training courses in how to use an energy simulation tool. They considered that learning manuals are neither complete nor intuitive. Only $6 \%$ indicated that manuals are written with an excellent quality. Some of the universities in Spain in which there are training courses on BPSTs, are the University of Navarra, UPM, E.T.S.A.V.A., and Etsav, among others. Associations of architects, such as Coam, Palencia, and the association of civil engineers in Madrid, also provide them. Private companies, such as the Foundation for construction, Zigurat E-Learning, and professional school of new technologies (CICE), also include courses on energy simulation tools as part of the training of their employees.

Regarding the architects' experience in the use of BPSTs, only $8 \%$ of respondents had been using them for more than 5 years. This answer indicates that most of them were not used during the respondents' university degrees. However, $60 \%$ of them had been using BPSTs for around 1 to 2 years, showing that such tools are commonly requested by their customers. In Spain, $44 \%$ of respondents performed calculations carried out by energy simulations. Half of the users considered that these tools are not suitable for architects, because they are not adapted to their knowledge and skills. Other research works evidence that more than $60 \%$ of early architects are satisfied with the use of these tools [71].

It is useful to expand the technical databases of building construction materials, with nomenclature for the knowledge of architects. As indicated in the state-of-the-art, an intuitive interface is the most valued element. Manuals with practical examples would facilitate the use of BPSTs. Another aspect that gives confidence to the user is that the results obtained in the initial stages of the design process are easily verified. During the conceptual development stage, a fast and straightforward workflow must be established to allow users to make the most generally useful decisions. Detailed simulations are not useful for most projects. Figure 5 illustrates the selection criteria of users in Spain. The most important criteria among recent graduate architects are compatibility between BPST and CAD and easy data entry. Other factors, such as the position in the market and compliance with national regulations, are not relevant. Complexity of use and a poor interface are barriers to the implementation of BPSTs. 


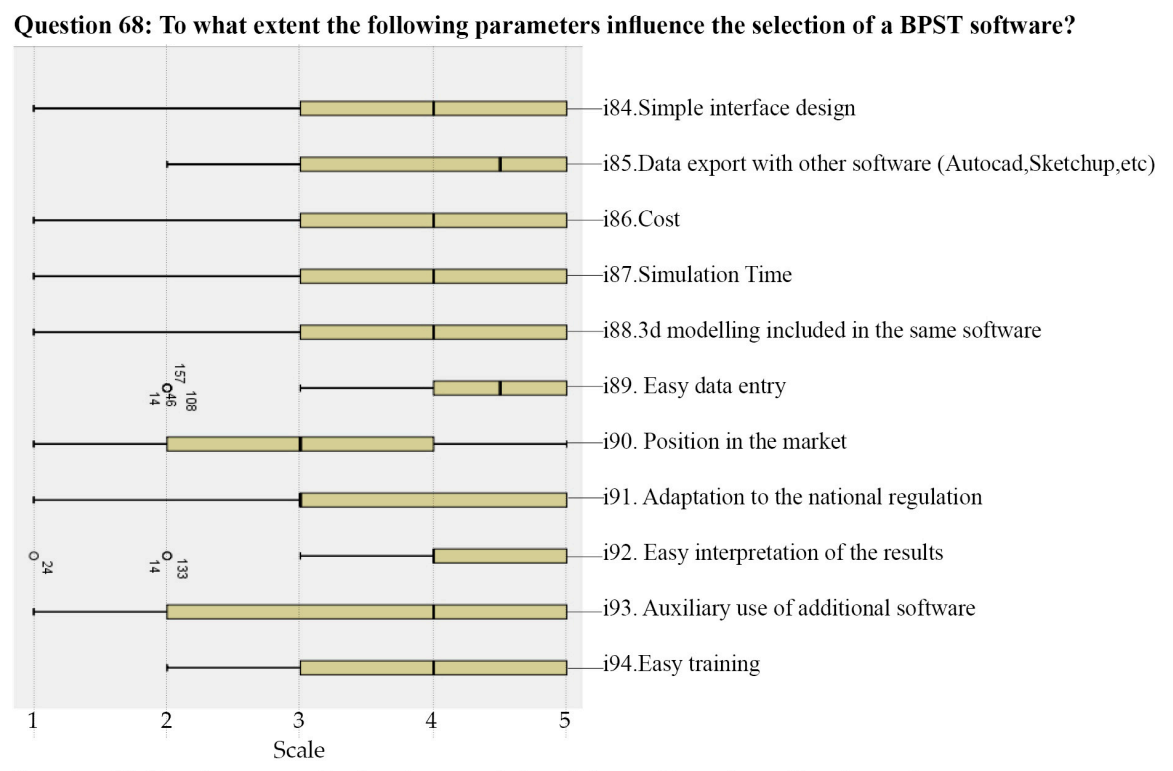

Question 70:To what extent do the characteristics of the tool interface affect its use?

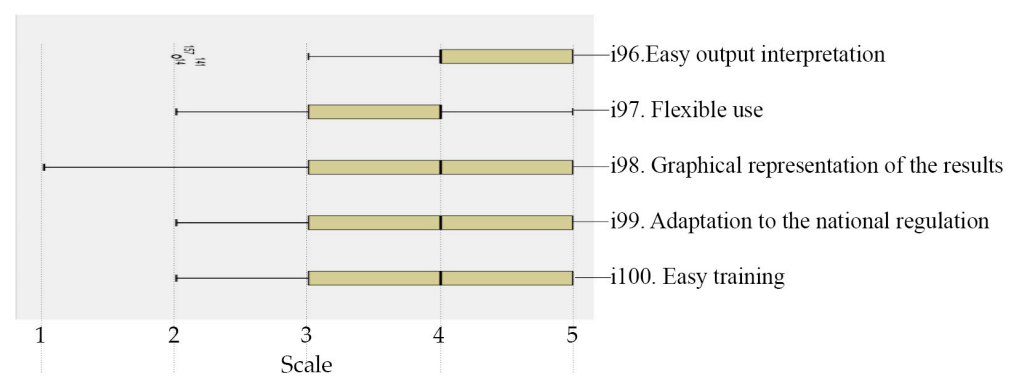

Question 71: To what extent do the following characteristics affect the use of BPSTs negatively?

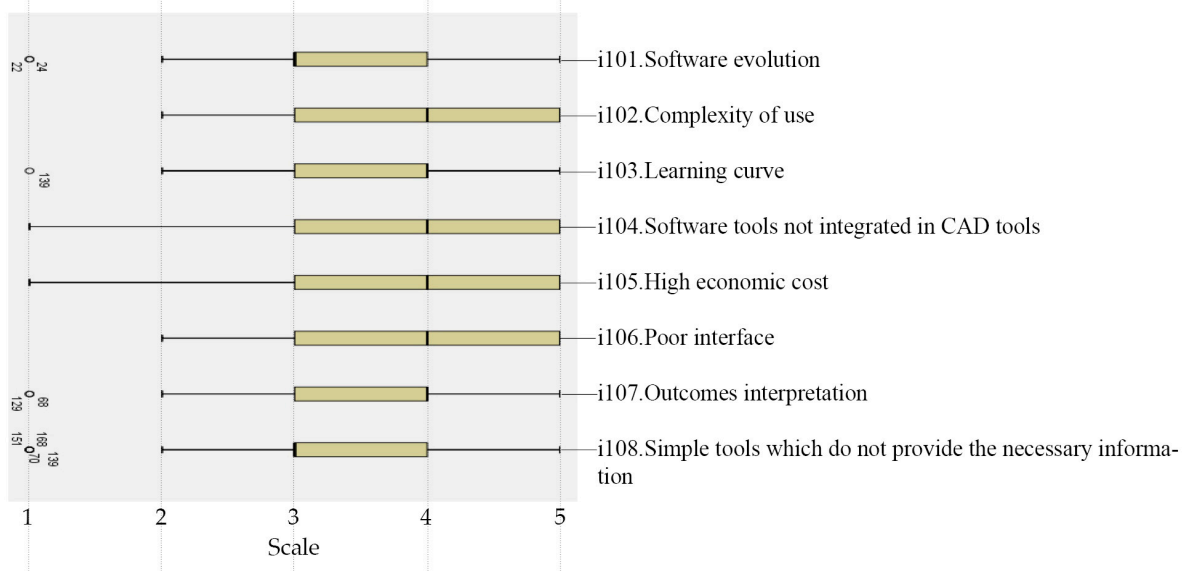

Figure 5. Relevant parameters and characteristics that lead to select BPSTs. 1 "Not at all important," 2 "Slightly Important," 3 “Important," 4 "Fairly Important," and 5 “Very Important".

\subsubsection{Selection Criteria of BPSTs}

The main criteria for the selection and evaluation of BPSTs are the users' needs. According to other research works, there is an essential difference between the priorities of architects and engineers in terms of selecting the importance of criteria related to their needs [15,19]. Recent graduate architects from Spain have been surveyed to establish comparisons with such results. Figures 6 and 7 show a comparison between the current and previous research works on the factors that lead respondents to select a BPST. Figure 7 illustrates the percentage of users that selected the values 1, 2, 3, 4 and 5 (1 "Not at all important," 2 "Slightly Important," 3 “Important," 4 "Fairly Important," and 5 "Very Important"). 
- Spain (Author's own) $\quad \square$ Attia et al. (2012) Architects s1 $\quad \square$ Attia et al. (2012) Architects s2

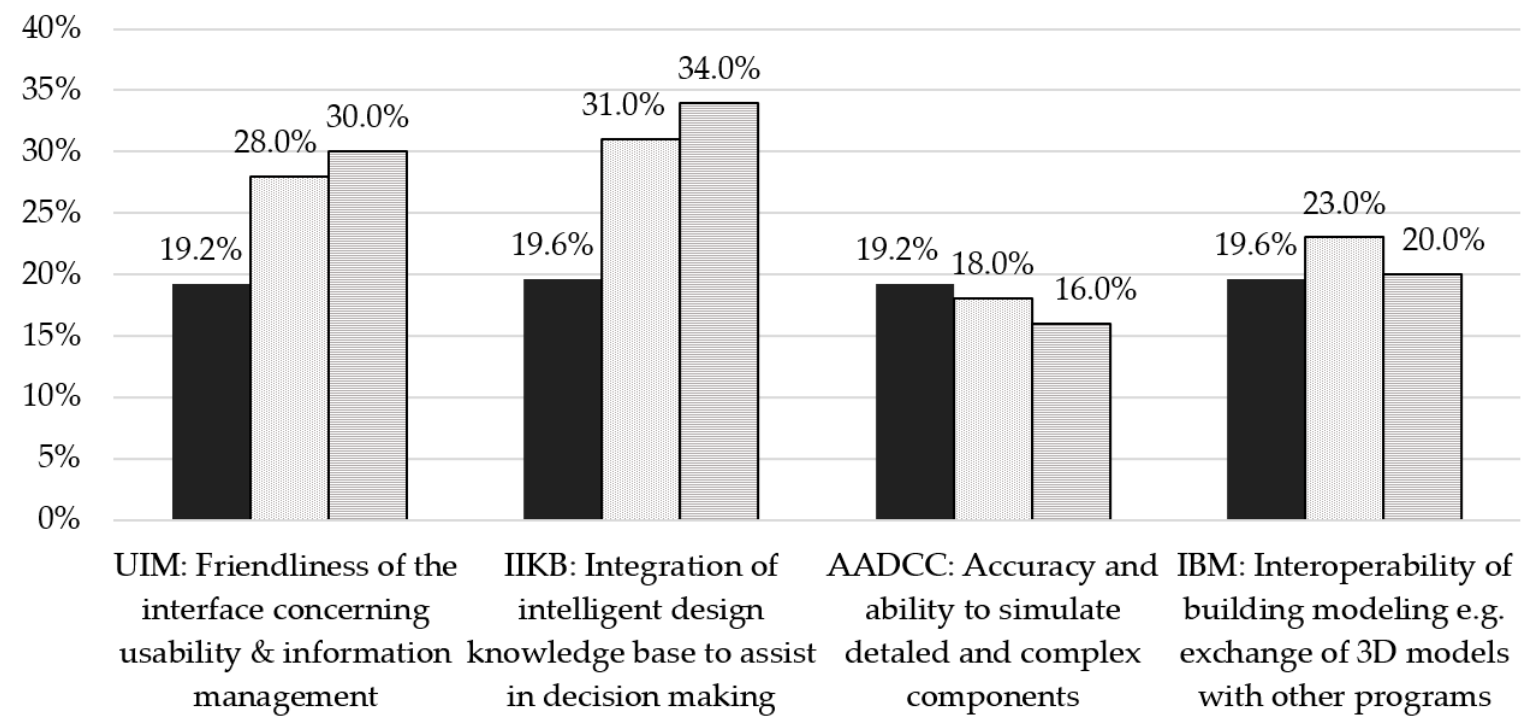

Figure 6. Priorities in selecting BPSTs. Comparison of the Spanish respondents considered in this study and those considered in the study of Attia, Shady et al., 2012. (Addressed only to BPSTs users).

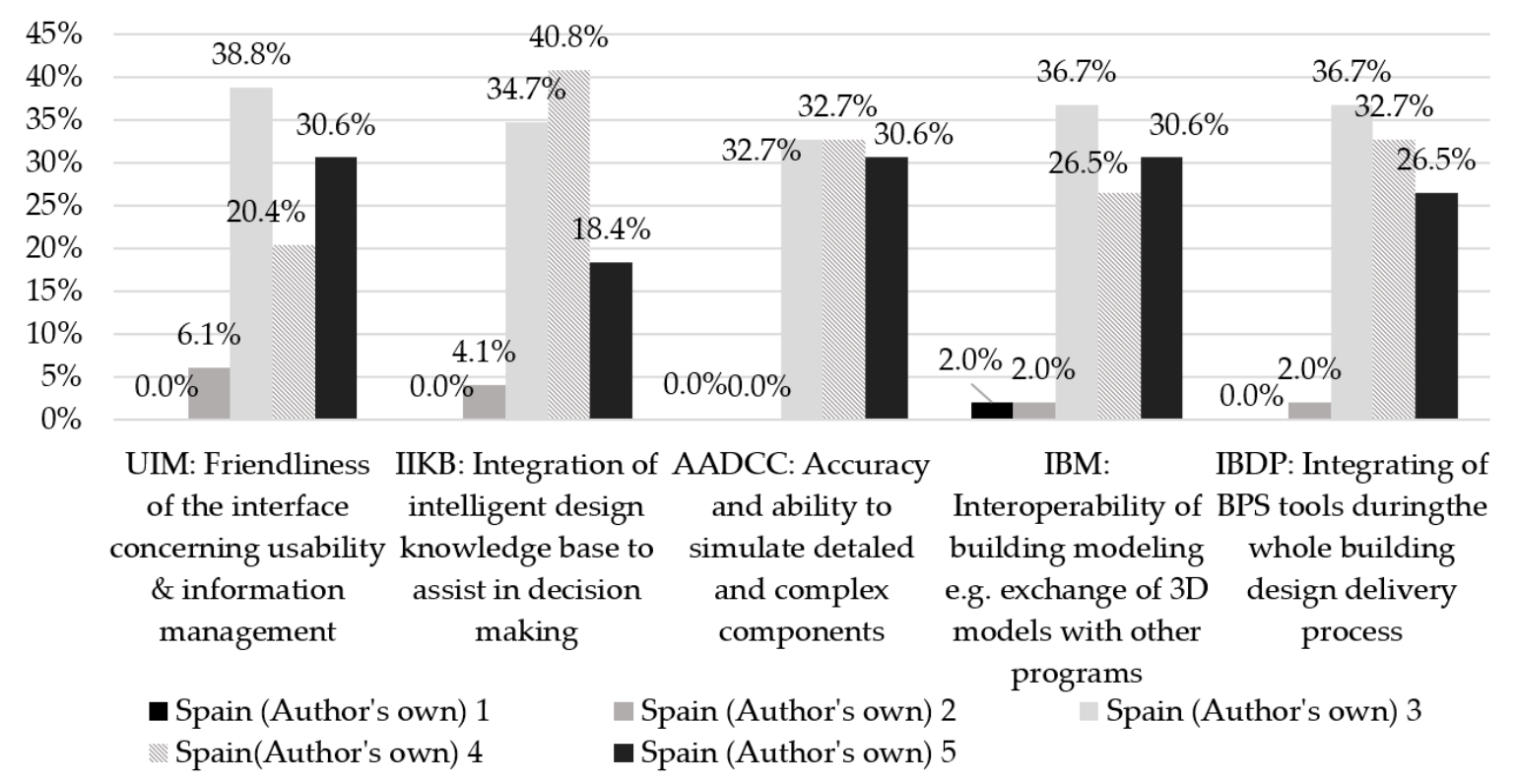

Figure 7. Priorities in selecting BPS tools. Comparison of different groups of respondents from Spain considered in this study (values 1 to 5). Level of importance: low (1), high (5). (Addressed only to BPSTs users).

The respondents considered themselves to have enough skills in the techniques of representation, data input and output, and the control of BPSTs. Regarding quantitative and qualitative advice concerning the influence of design decisions on the Integration of Intelligent design Knowledge-Base (IIKB), they could optimize design solutions, involve what-if scenarios, and verify the reliability of the tool. According to the Spanish recent graduate architects' viewpoint, the Accuracy of tools and the Ability to simulate Detailed and Complex building Components (AADCC), including analytical and empirical comparative tests, are crucial. They are not concerned with the calibration of uncertainty and the level of quality of the simulation results concerning the exchange of information with CAD software. 
The results of the study show the deficiencies that currently exist concerning energy simulation. While users regarded energy simulation as a topic of the most significant interest for society (3.9/5 as mean value), its use was not required in their universities (45.6\%). The respondents considered this fact a deficiency, with $62 \%$ of them considering it urgent to introduce this new teaching material into university syllabi. The current level of training that exists in energy analysis is poorly valued (2.34/5, with a standard deviation of 1.08 and a mode and median of 2/5). Besides, university hardly encourages the use of BPSTs (3/5). The inclusion of BPSTs in the syllabi or the final degree project $(73.7 \%)$ can help solve deficiencies. This can be carried out through lectures, workshops with experts $(68.4 \%)$, as a part of a master's degree or within PhD studies $(34.5 \%)$, and can be encouraged by the associations of architects $(29.2 \%)$. The respondents considered that the data output is not adapted to the needs of an architectural project design (2.72/5). The facilitation of the use of BPSTs in architecture must be solved by the prior training of students $(76.6 \%)$. Of the surveyed architects, $100 \%$ considered that the existence of a manual with equivalences between the results exported from BPSTs and the passive strategies used by architects during the design of their projects (5) is necessary. The creation of manuals with a clear and defined methodology that can be easily understood by an architect is a feasible solution. It is necessary to provide more information, with examples of practical use. BPSTs must always provide added information to the architectural design, without involving an increase in the time cost allocated to the project. The Administration must constructively encourage its use through incentives. Besides, it must be responsible for reviewing the projects, before granting a license. The ultimate objective should be the production of supporting documentation required by the project to continue promoting its use.

Nowadays, all kinds of professionals, both architects and multidisciplinary workers, are devoted to energy consulting. As the regulations involved become much stricter each day, it is more necessary than ever to use BPSTs. Therefore, consultants of façades, structures, or landscaping, among other things, have to support architectural design and construction. Architects will use these tools in their projects, if they do not involve a high cost. The time necessary to develop a project, especially in its administrative aspects, is quite high in Spain. Therefore, BPSTs must offer quick information, with quality results, thus facilitating the decision-making process (i.e., shape, facilities, and equipment). This aspect would be beneficial for obtaining a building design with the minimum energy consumption and investing very little extra time. It is crucial to be precise about these concepts from the very early stages of the design of a building, as this can save a lot of time when the project is developed in detail.

The following survey, shown in Figure 8, is addressed to recent graduate architects and users of BPST. The information has been elaborated using the SPSS software and applying the Likert scale. The level of agreement or disagreement with a statement is specified by a scale: 1 Strongly disagree, 2 Disagree, 3 Undecided, 4 Agree, and 5 Strongly agree. The respondents considered that user-friendly HVAC templates and reliable error-checking to ensure the correctness of results are the most important factors when it comes to selecting a BPST (question 72). As for the characteristics of knowledge (question 73), four aspects are considered to be relevant: qualitative and quantitative knowledge about the design decisions, design parameters in the early design stage, passive design measures, and a complete library of construction components. Meeting the requirements of codes, life cycle assessments, and a low cost of buildings are the aspects with a lower value. When it comes to assessing abilities (question 74), the optimization of a building envelope and natural ventilation is the primary concern. The interoperability (question 75) and the capability to interchange information from modeling, visualization, and simulation tools is the essential aspect. Finally, the process of iteration between design and energy simulation seems to be a crucial characteristic of design (question 76). In sum, interoperability is the most important characteristic, and knowledge is the least important characteristic. 
Question 72.To what extent do you think the following characteristics about the use of BPSTs are important?

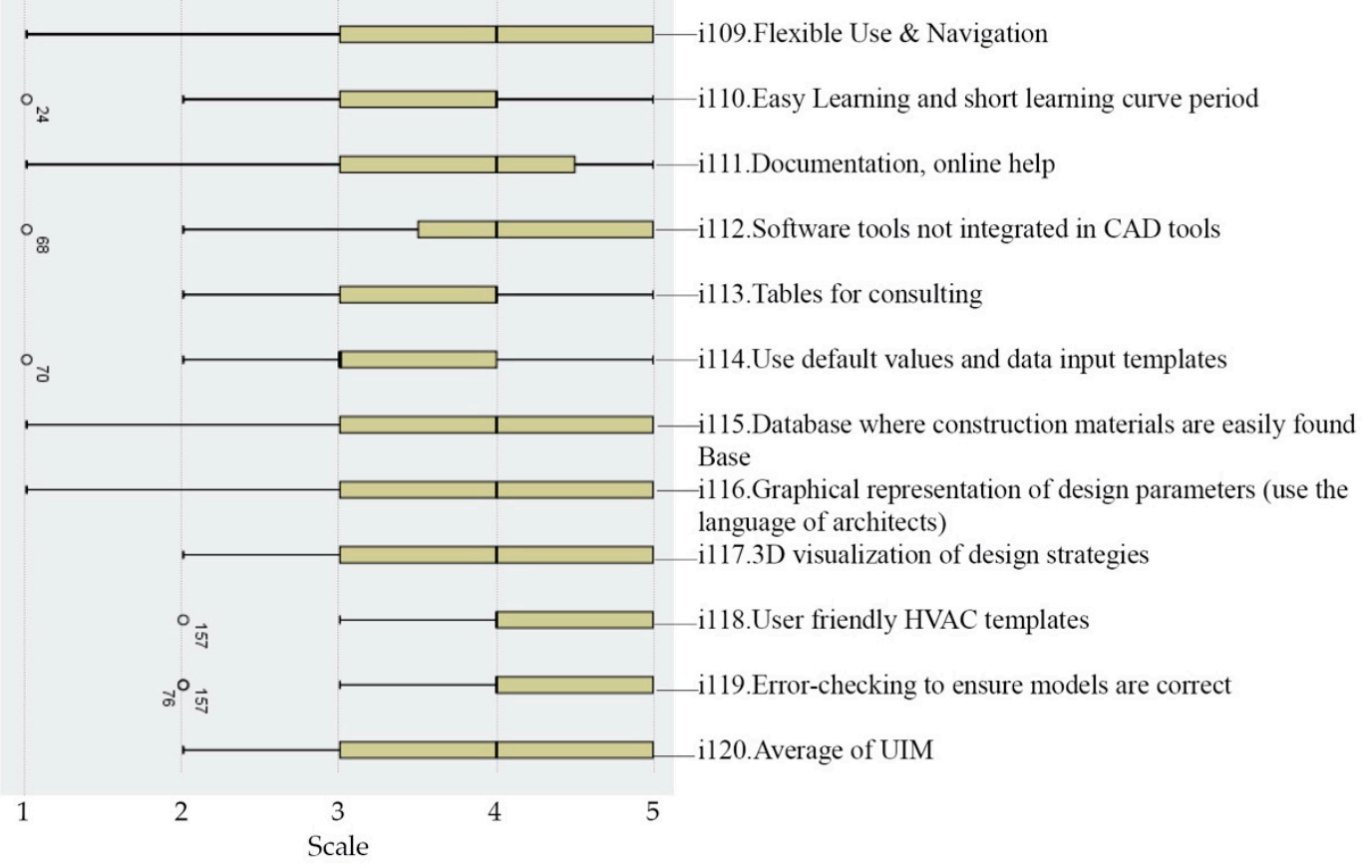

Question 73. To what extent do you think the following characteristics about knowledge are important?

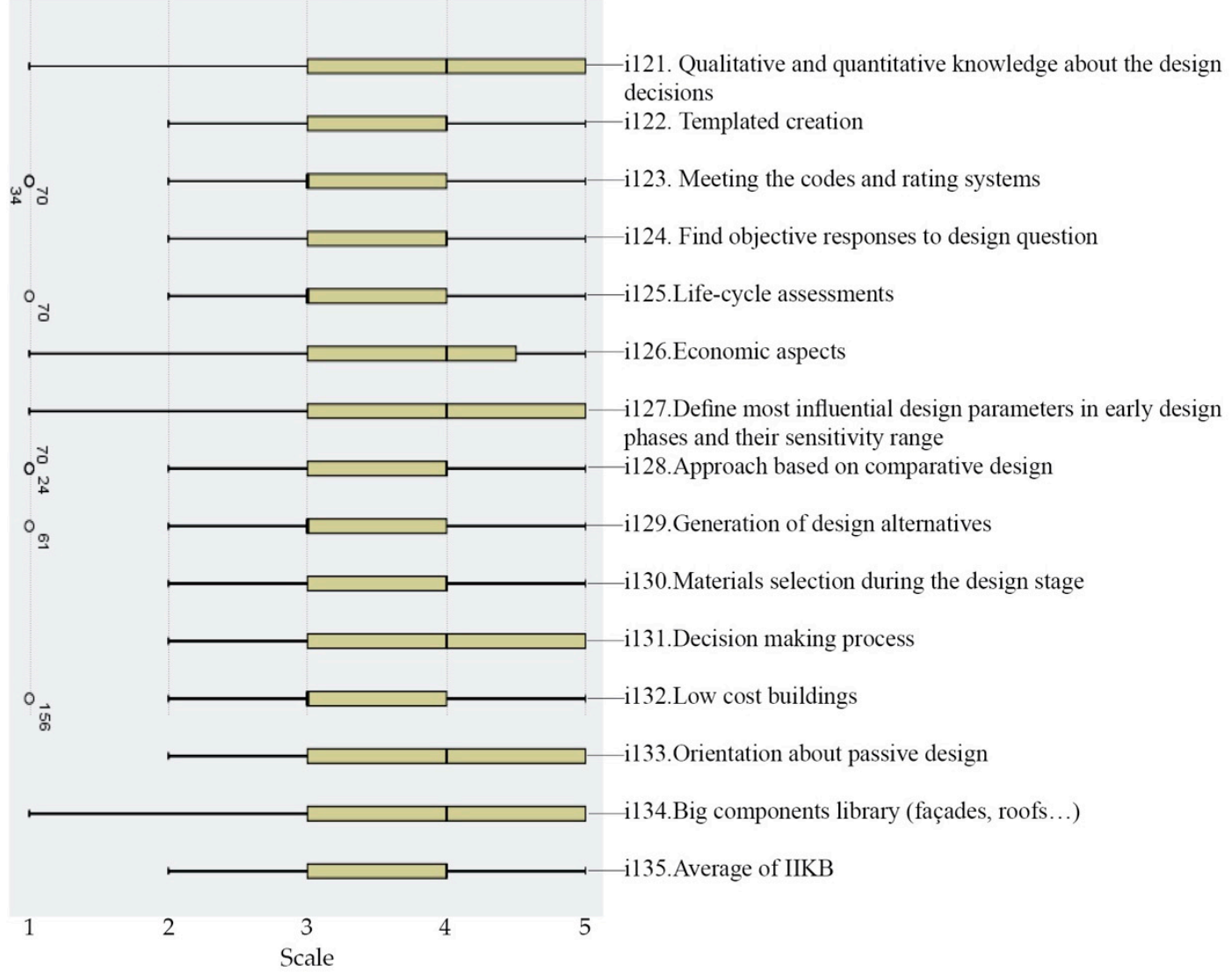

Figure 8. Cont. 
Question74. To what extent do you think the following characteristics about ABILITIES are important?

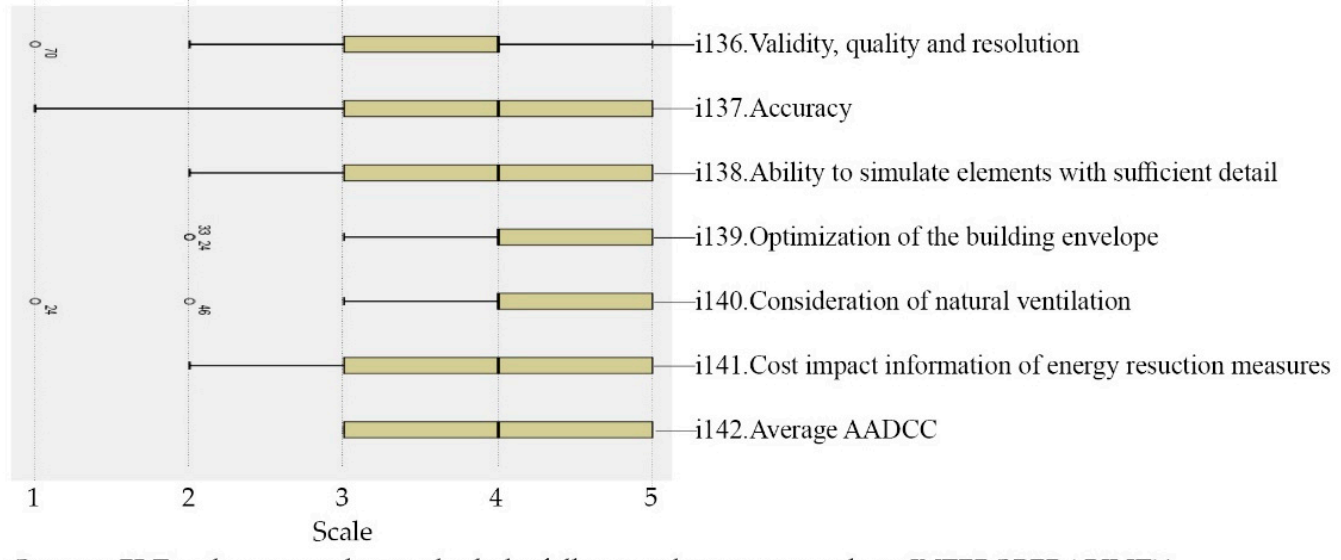

Question75.To what extent do you think the following characteristics about INTEROPERABILITY are important?

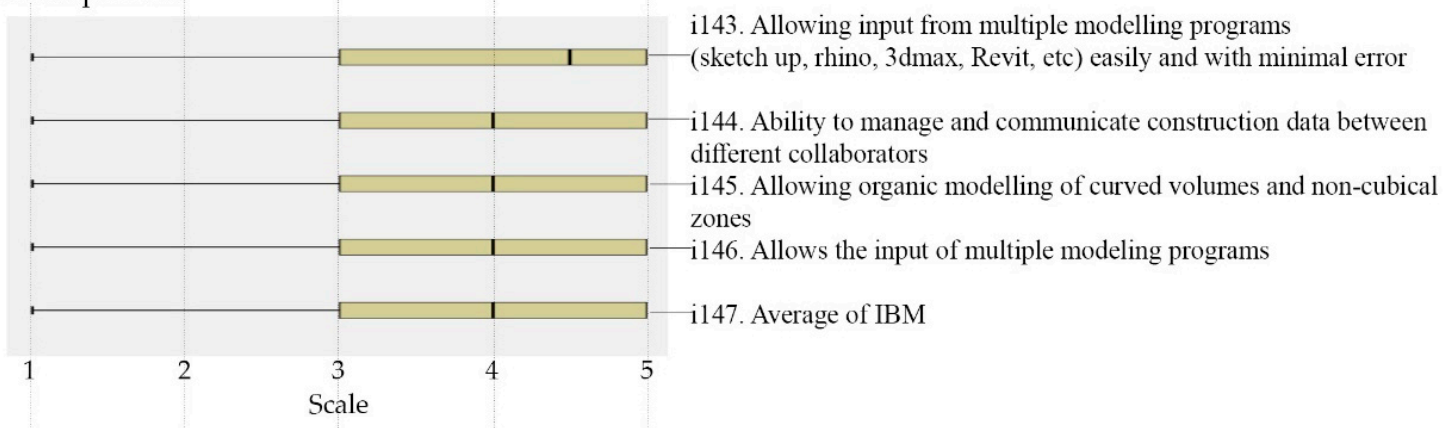

Question76.To what extent do you think the following characteristics about DESIGN are important?

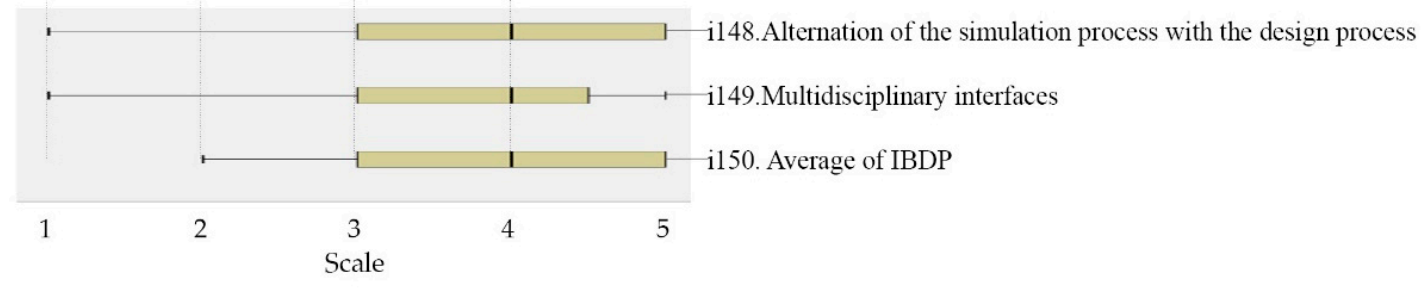

Figure 8. Relevant parameters and characteristics that lead to select BPSTs in Spain. The respondents have evaluated the following tools: UIM, IIKB, AADCC, IBM and IBDP. Scale 1 (little) to 5 (much). A Cronbach's Alpha greater than 0.9 is excellent (0.97).

\section{Conclusions}

Given the findings of the literature review and the results of this research, it can be concluded that there is a significant deficiency in Spain in the current training of architecture students at universities and energy-efficiency interests worldwide. There have been numerous investigations in other countries that indicate that the use of BPSTs is essential and that architects should use them. However, it is demonstrated that the advance of their use in Spain over recent years is far from satisfactory.

Reflection on the results of this research also suggests that this issue should be urgently addressed and that the pedagogical approach in the Universities of Spain must now be adapted to the energy regulations.

One of the main reasons for the non-use of BPSTs by recent graduate architects is that they consider them to be strange, uncomfortable, and challenging to learn. To bridge the deficiencies and thus allow BPSTs to become an essential practice, the general aspects of BPSTs, such as a smooth interaction and understanding, although without reaching extreme levels, should be the focus. If simulations 
in conceptual phases became accessible and user-friendly, the respondents would consider moving toward the use of more specific tools.

According to the results of the survey, the authors elaborated a set of concrete recommendations to overcome the gap observed between the architecture curricula and the first professional experiences of recent graduate architects in Spain. These recommendations are derived from the results section of this paper and target software developers to consider the data output and the simulation results in a way that meets architects' needs. It also guides educators and educational administrations towards the implementation of urgent measures that would contribute to a better technical and energy-efficient consolidation of competency training for architects in Spain.

Recommendations to software developers:

Section 3.2.1 shows the criteria for selecting BPSTs. The ability to interchange information from modeling, visualization, and simulation tools, the interface, and the easy entry of data are the essential aspects that lead recent graduate architects to select BPSTs.

Design Builder provides a complete set of results that include stationary and non-stationary analyses of the thermal behavior of buildings. Its interface is adapted to architects' needs, and it is close to other CAD tools that are used by architects during the conceptual design stage. The Design Builder software developer provides universities with package discounts for students so that it can be easily implemented in architecture curricula.

The visualization of simulation results is the second aspect of the improvement of most BPSTs. A more friendly visualization of results would help educators include these tools in architecture courses. Visual documents with graphs can show how specific parameters influence the quantitative and qualitative behavior of buildings. A direct relationship between the design decision and its impact on the thermal loads would be a powerful output for BPSTs.

Recommendations to educators:

The analysis of the results, shown in Section 3.1.2, shows that recent graduate architects lack knowledge of BPSTs. The authors propose solving this deficiency by incorporating Building Energy Simulation into two different areas of architecture curricula: design courses and building systems courses. Design courses should encourage the use of BPSTs through assignments on the influence of the orientation of buildings, the shape factor, and the wall-to-window ratio. The results of simulations should justify design decisions in the conceptual stage of the design process.

Building systems courses should include the use of BPSTs to assess thermal parameters, such as solar reflectance and transmittance, and their influence on the heating and cooling demand. Absorptance is a parameter that has been traditionally neglected in building performance and can be easily included through the use of simulation tools.

Incorporating BPSTs in syllabi requires elaborating innovative teaching materials related to the discussion of simulation results.

In previous papers, researchers have shown solutions, such as innovative teaching material, that allow for the successful introduction of BPSTs into the Spanish Architecture schools. Lecture-based approaches are not enough, and only the proposal of practical examples in teaching can solve the existing deficiencies.

The findings of this research can be useful for professors and research staff interested in teaching the environmental aspects of architecture, as well as in the advancement of strategies that promote an effective way of learning through methodologies used during the future professional careers of recent graduate architects.

Because the architect must leave a mark on society, efficiency must be something tangible and logically integrated into the project areas. BPSTs can be included in university curricula, and students should be encouraged to use them during their studies. They should combine their creative designs with energy saving measures.

Supplementary Materials: The following are available online at http://www.mdpi.com/1996-1073/13/5/1134/s1, Appendix A1; Appendix A2 and Appendix A3. 
Author Contributions: Conceptualization, M.-M.F.-A., R.-A.G.-L.; methodology, R.-A.G.-L.; software, M.-M.F.-A.; validation, M.-M.F.-A., R.-A.G.-L.; formal analysis, M.-M.F.-A.; investigation, M.-M.F.-A.; resources, R.-A.G.-L.; data curation, J.-M.d.-R.; writing-original draft preparation, M.-M.F.-A.; writing—review and editing, M.-M.F.-A., R.-A.G.-L, F.d.A.G.; visualization, R.-A.G.-L.; supervision, R.-A.G.-L.; project administration, R.-A.G.-L.; funding acquisition, R.-A.G.-L. All authors have read and agreed to the published version of the manuscript.

Funding: The authors wish to thank CEU San Pablo University Foundation for the predoctoral scholarship granted to co-author Maria-Mar Fernandez-Antolin within its FPI Program and for the funds dedicated to the Project CEU-Banco Santander (Ref: MVP19V14) provided by CEU San Pablo University and financed by Banco Santander.

Acknowledgments: Thanks are due to Arie Group from the Institute of Technology within CEU San Pablo University and the laboratory within CEU San Pablo University because of the Design Builder software licenses provided. Finally, the authors wish to thank both CEINDO CEU and Banco Santander for the international mobility scholarship granted to co-author Maria-Mar Fernandez-Antolin in order to develop an external research stay at Department of Civil Engineering and Architecture within the University of Catania.

Conflicts of Interest: The authors declare that they have no conflict of interest.

\section{References}

1. European Renewable Energy Council. RE-Thinking 2050-A 100\% Renewable Energy Vision for the European Union. 2011. Available online: http://www.erec.org/ (accessed on 25 June 2019).

2. Wagner, S.; Mellblom, P. The next generation of energy efficient building design: Where are we and where should we be going? In Proceedings of the Building Enclosure Science and Technology, BEST Conference, Minneapolis, MN, USA, 10-12 June 2008.

3. Cao, X.; Dai, X.; Liu, J. Building energy-consumption status worldwide and the state-of-the-art technologies for zero-energy buildings during the past decade. Energy Build. 2016, 128, 198-213. [CrossRef]

4. Kazim, A.M. Assessments of primary energy consumption and its environmental consequences in the united arab emirates. Renew. Sustain. Energy Rev. 2007, 11, 426-446. [CrossRef]

5. Paryudi, I. Architects and energy simulations tool. Int. J. Sci. Technol. Res. 2015, 4, 80-82.

6. Attia, S.; Beltrán, L.; De Herde, A.; Hensen, J. "Architect friendly": A comparison of ten different building performance simulation tools. In Proceedings of the IBPSA 2009-International Building Performance Simulation Association Conference and Exhibition, Glasgow, UK, 27-30 July 2009; pp. 204-211.

7. Mahdavi, A. The human dimension of building performance simulation. In Proceedings of the Building Simulation 2011: 12th Conference of International Building Performance Simulation Association, Sydney, Australia, 14-16 November 2011; pp. K16-K33.

8. Kusuda, T. Early history and future prospects of building system simulation. In Proceedings of Building Simulation; IBPSA: Kyoto, Japan, 1999; Available online: http://www.ibpsa.org/proceedings/BS1999/BS99_P01.pdf (accessed on 9 September 2019).

9. Hensen, J.L.M. Towards more effective use of building performance simulation in design. In Proceedings of the 7th International Conference on Design \& Decision Support Systems in Architecture and Urban Planning, Eindhoven, The Netherlands, 2-5 July 2004; pp. 2-5.

10. Punjabi, S.; Miranda, V. Development of an integrated building design information interface. In Proceedings of the IBPSA 2005-International Building Performance Simulation Association, Montréal, QC, Canada, 15-18 August 2005; pp. 969-976.

11. Attia, S.; Hensen, J.L.M.; Beltran, L.; De Herde, A. Selection criteria for building performance simulation tools: Contrasting architects' and engineers' needs. J. Build. Perform. Simul. 2012, 5, 155-169. [CrossRef]

12. AIA Energy Modeling Working Group. An Architect's Guide to Integrating Energy Modeling in the Design Process. 2012. Available online: http://content.aia.org/sites/default/files/2016-04/Energy-Modeling-DesignProcess-Guide.pdf (accessed on 3 February 2019).

13. Mahdavi, A. People in building performance simulation. In Building Performance Simulating for Design and Operation; Routledge: Abingdon-on-Thames, UK, 2012; pp. 56-83. [CrossRef]

14. Holm, D. Building thermal analyses-what the industry needs-the architects perspective. Build. Environ. 1993, 28, 405-407. [CrossRef]

15. Attia, S. State of the Art of Existing Early Design Simulation Tools for Net Zero Energy Buildings: A Comparison of Ten Tools; Architecture et Climat: Louvain La Neuve, Belgium, 2011. 
16. Weytjens, L.; Verbeeck, G. Towards 'architect-friendly' energy evaluation tools. In Proceedings of the Spring Simulation Multiconference 2010, SpringSim'10, Orlando, FL, USA, 11-15 April 2010. [CrossRef]

17. Soebarto, V.; Hopfe, C.J.; Crawley, D.; Rawal, R. Capturing the views of architects about building performance simulation to be used during design processes. In Proceedings of the 14th International Conference of IBPSA-Building Simulation 2015, BS 2015, Hyderabad, India, 7-9 December 2015; pp. 1480-1487.

18. Naboni, E. Environmental simulation tools in architectural practice: The impact on processes, methods and design. In Proceedings of the PLEA 2013-29th Conference, Sustainable Architecture for a Renewable Future, Munich, Germany, 10-12 September 2013.

19. Attia, S.; Gratia, E.; De Herde, A.; Hensen, J.L.M. Simulation-based decision support tool for early stages of zero-energy building design. Energy Build. 2012, 49, 2-15. [CrossRef]

20. Mahdavi, A. Computational decision support and the building delivery process: A necessary dialogue. Autom. Constr. 1998, 7, 205-211. [CrossRef]

21. Morbitzer, C.; Strachan, P.; Spires, B.; Cafferty, D.; Webster, J. Integration of building simulation into the design process of an architectural practice. In Proceedings of the Seventh International IBPSA Conference, Rio de Janeiro, Brazil, 13-15 August 2001.

22. Lam, K.P.; Wong, N.H.; Feriady, H. A study of the use of performance-based simulation tools for building design and evaluation in Singapore. In Proceedings of the Sixth IBPSA Conference, Kyoto, Japan, 13-15 September 1999; pp. 675-682.

23. Schlueter, A.; Thesseling, F. Building information model based energy/exergy performance assessment in early design stages. Autom. Constr. 2009, 18, 153-163. [CrossRef]

24. Paradis, R. Energy Analysis Tools. Steven Winter Associates, Inc., 2010. Available online: http://Www.Wbdg. Org/Resources/Energyanalysis.Php (accessed on 15 May 2019).

25. Lam, K.P.; Huang, Y.C.; Zhai, C. Energy Modeling Tools Assessment for Early Design Phase; Center for Building Performance and Diagnostics School of Architecture, Carnegie Mellon University: Pittsburgh, PA, USA, 2004.

26. Bambardekar, S.; Poerschke, U. The architect as performer of energy simulation in the early design stage. In Proceedings of the IBPSA 2009-International Building Performance Simulation Association, Glasgow, UK, 27-30 July 2009; pp. 1306-1313.

27. Pilgrim, M.J. The Application of Visualisation Techniques to the Process of Building Performance Analysis. Doctoral Dissertation, Loughborough University, Loughborough, UK, 2003.

28. de Souza, C.B. A critical and theoretical analysis of current proposals for integrating building thermal simulation tools into the building design process. J. Build. Perform. Simul. 2009, 2, 283-297. [CrossRef]

29. Brunsgaard, C.; Dvořáková, P.; Wyckmans, A.; Stutterecker, W.; Laskari, M.; Almeida, M.; Op't Veld, P. Integrated energy design-Education and training in cross-disciplinary teams implementing energy performance of buildings directive (EPBD). Build. Environ. 2014, 72, 1-14. [CrossRef]

30. Molthan-Hill, P.; Worsfold, N.; Nagy, G.J.; Leal Filho, W.; Mifsud, M. Climate change education for universities: A conceptual framework from an international study. J. Clean. Prod. 2019, 226, 1092-1101. [CrossRef]

31. Janmaimool, P.; Khajohnmanee, S. Roles of Environmental System Knowledge in Promoting University Students' Environmental Attitudes and Pro-Environmental Behaviors. Sustainability 2019, 11, 4270. [CrossRef]

32. Mavromatidis, L.E.; Mavromatidi, A.; Lequay, H. The unbearable lightness of expertness or space creation in the "climate change" era: A theoretical extension of the "constructal law" for building and urban design. City Cult. Soc. 2014, 5, 21-29. [CrossRef]

33. Celadyn, W. Postgraduate studies and sustainable architecture. Glob. J. Eng. Educ. 2018, 20, 54-58.

34. Mavromatidis, L. Coupling architectural synthesis to applied thermal engineering, constructal thermodynamics and fractal analysis: An original pedagogic method to incorporate "sustainability" into architectural education during the initial conceptual stages. Sustain. Cities Soc. 2018, 39, 689-707. [CrossRef]

35. Vehmaa, A.; Karvinen, M.; Keskinen, M. Building a More Sustainable Society? A Case Study on the Role of Sustainable Development in the Education and Early Career of Water and Environmental Engineers. Sustainability 2018, 10, 2605. [CrossRef]

36. Gusc, J.; Heijes, C. “Oh This Learning, What a Thing It Is!"-Putting Sustainability First in Teaching Techniques and in Content. Sustainability 2018, 10, 2803. [CrossRef] 
37. Boarin, P.; Martinez-Molina, A.; Juan-Ferruses, I. Understanding students' perception of sustainability in architecture education: A comparison among universities in three different continents. J. Clean. Prod. 2020, 248, 119237. [CrossRef]

38. Alsaadani, S.; Bleil De Souza, C. Performer, consumer or expert? A critical review of building performance simulation training paradigms for building design decision-making. J. Build. Perform. Simul. 2019, 12, 289-307. [CrossRef]

39. López de Asiain Alberich, M. "La Formación Medioambiental del Arquitecto". Hacia un Programa de Docencia Basado en la Arquitectura y el Medioambiente; Universitat Politècnica de Catalunya: Barcelona, Spain, 2005.

40. Oliveira, S.; Marco, E.; Gething, B.; Robertson, C. Exploring energy modelling in architecture logics of investment and risk. Energy Procedia 2017, 111, 61-70. [CrossRef]

41. Oliveira, S.; Marco, E.; Gething, B.; Organ, S. Evolutionary, not revolutionary-logics of early design energy modelling adoption in UK architecture practice. Archit. Eng. Des. Manag. 2017, 13, 168-184. [CrossRef]

42. Oxman, R. Digital architecture as a challenge for design pedagogy: Theory, knowledge, models and medium. Des. Stud. 2008, 29, 99-120. [CrossRef]

43. Urquidi-Martín, A.; Tamarit-Aznar, C.; Sánchez-García, J. Determinants of the Effectiveness of Using Renewable Resource Management-Based Simulations in the Development of Critical Thinking: An Application of the Experiential Learning Theory. Sustainability 2019, 11, 5469. [CrossRef]

44. Charles, P.P.; Thomas, C.R. Four approaches to teaching with building performance simulation tools in undergraduate architecture and engineering education. J. Build. Perform. Simul. 2009, 2, 95-114. [CrossRef]

45. Reinhart, C.F.; Dogan, T.; Ibarra, D.; Samuelson, H.W. Learning by playing-teaching energy simulation as a game. J. Build. Perform. Simul. 2012, 5, 359-368. [CrossRef]

46. Aksit, O.; Wiebe, E.N. Exploring force and motion concepts in middle grades using computational modeling: A classroom intervention study. J. Sci. Educ. Technol. 2019. [CrossRef]

47. Khan, S. New pedagogies on teaching science with computer simulations. J. Sci. Educ. Technol. 2011, 20, 215-232. [CrossRef]

48. Sherman, G.; Byers, A.; Rapp, S. Evaluation of online, on-demand science professional development material involving two different implementation models. J. Sci. Educ. Technol. 2008, 17, 19-31. [CrossRef]

49. Zucker, A.A.; Hug, S.T. Teaching and learning physics in a 1: 1 laptop school. J. Sci. Educ. Technol. 2008, 17, 586-594. [CrossRef]

50. Hetherington, R.; Laney, R.; Peake, S.; Oldham, D. Integrated building design, information and simulation modelling: The need for a new hierarchy. In Proceedings of the Building Simulation 2011: 12th Conference of International Building Performance Simulation Association, Sydney, Australia, 14-16 November 2011; pp. 2241-2248.

51. Tupper, K.; Franconi, E.; Chan, C.; Hodgin, S.; Buys, A.; Jenkins, M. Building energy modeling: Industry-wide issues and potential solutions. In Proceedings of the 12th Conference of International Building Performance Simulation Association, Sydney, Australia, 14-16 November 2011.

52. Fernandez-Antolin, M.-M.; del-Río, J.-M.; Gonzalez-Lezcano, R.-A. Influence of Solar Reflectance and Renewable Energies on Residential Heating and Cooling Demand in Sustainable Architecture: A Case Study in Different Climate Zones in Spain Considering Their Urban Contexts. Sustainability 2019, 11, 6782. [CrossRef]

53. Jesús, F.-M.; Irene, P.-C.; Roberto Alonso, G.-L.; Cristina, P.; Víctor, E.; Rafael, A.; Alberto, M. Methodology for the Study of the Envelope Airtightness of Residential Buildings in Spain: A Case Study. Energies 2018, 11, 704. [CrossRef]

54. Feijó-Muñoz, J.; González-Lezcano, R.A.; Poza-Casado, I.; Padilla-Marcos, M.Á.; Meiss, A. Airtightness of residential buildings in the Continental area of Spain. Build. Environ. 2019, 148, 299-308. [CrossRef]

55. Hayden, I. An evaluation of the design and use of applied visual interactive resources for teaching building regulations in higher education built environment programmes. Archit. Eng. Des. Manag. 2019, 15, 159-180. [CrossRef]

56. Fernandez-Antolin, M.; del Río, J.M.; Costanzo, V.; Nocera, F.; Gonzalez-Lezcano, R. Passive design strategies for residential buildings in different spanish climate zones. Sustainability 2019, 11, 4816. [CrossRef]

57. Herranen, J.; Vesterinen, V.-M.; Aksela, M. From Learner-Centered to Learner-Driven Sustainability Education. Sustainability 2018, 10, 2190. [CrossRef] 
58. Marcu, S. Refugee Students in Spain: The Role of Universities as Sustainable Actors in Institutional Integration. Sustainability 2018, 10, 2082. [CrossRef]

59. Carrera, J.; Ramírez-Hernández, D. Innovative Education in MOOC for Sustainability: Learnings and Motivations. Sustainability 2018, 10, 2990. [CrossRef]

60. Altomonte, S.; Rutherford, P.; Wilson, R. Mapping the way forward: Education for sustainability in architecture and urban design. Corp. Soc. Responsib. Environ. Manag. 2014, 21, 143-154. [CrossRef]

61. Domenica Iulo, L.; Gorby, C.; Poerschke, U.; Nickolas Kalisperis, L.; Woollen, M. Environmentally conscious design-educating future architects. Int. J. Sustain. High. Educ. 2013, 14, 434-448. [CrossRef]

62. EDUCATE. 2009. Available online: http://cort.as/-EURy (accessed on 5 March 2019).

63. Pallant, J. SPSS Survival Manual: A Step by Step Guide to Data Analysis Using SPSS for Windows; McGraw-Hill Education, Open University Press: New York, NY, USA, 2007; ISBN 10-0-335-22366-4.

64. Denzin, N.; Lincoln, Y. The Sage Handbook of Qualitative Research; Sage: Thousand Oaks, CA, USA, 2005.

65. Keller, J.M. Motivational Design for Learning and Performance: The ARCS Model Approach; Springer: Berlin/Heidelberg, Germany, 2009.

66. Guilford, J.P. Fundamental Statistics in Psychology and Education; McGraw-Hill: New York, NY, USA, 1950.

67. Baba, A.; Mahjoubi, L.; Olomolaiye, P.; Booth, C. Architects requirements of decision support tools to deliver low impact housing design in the UK: Insights and recommendations. J. Environ. Earth Sci. 2013, 3, $22-32$.

68. Weytjens, L.; Attia, S.; Verbeeck, G.; De Herde, A. The 'architect-friendliness' of six building performance simulation tools: A comparative study. Int. J. Sustain. Build. Technol. Urban Dev. 2011, 2, 237-244. [CrossRef]

69. Attia, S. Building Performance Simulation Tools: Selection Criteria and User Survey; Architecture et Climat: Louvain La Neuve, Belgium, 2010.

70. Zapata-Lancaster, G.; Tweed, C. Tools for low-energy building design: An exploratory study of the design process in action. Archit. Eng. Des. Manag. 2016, 12, 279-295. [CrossRef]

71. Mahdavi, A.; Feurer, S.; Redlein, A.; Suter, G. An inquiry into the building performance simulation tools usage by architects in Austria. In Proceedings of the Eight International IBPSA Conference, Eindhoven, The Netherlands, 11-14 August 2003; pp. 777-784.

(C) 2020 by the authors. Licensee MDPI, Basel, Switzerland. This article is an open access article distributed under the terms and conditions of the Creative Commons Attribution (CC BY) license (http://creativecommons.org/licenses/by/4.0/). 